\title{
The Influence of the Age of Sugarcane on its Leaf-Nutrient (N-P-K) Content
}

\author{
George Samuels ${ }^{1}$
}

\section{INTRODUCTION}

The major plant nutrients (N-P-K) do not remain at a constant level throughout the life of the sugarcane plant. The level of a particular nutrient element in the cane leaf is influenced by the amount of that nutrient available to the plant from the soil and the presence and interaction with other nutrient elements in the soil and plant. But, aside from the supply of the nutrient itself, there are other important factors which influence the amount of nutrient found present in the cane plant. The more important of these factors are: Moisture, temperature, and age of the cane.

The influence of the age of the leaf or sheath sample on its nutrient content becomes an important consideration to the agronomist engaged in tissue analysis of sugarcane, whether using "foliar-diagnosis" or "croplogging" systems. In foliar-diagnosis technique as practiced in Puerto Rico $(9), 2$ the object of the agronomist is to obtain sugarcane leaf samples at a cane age of 3 months. The reason is that the best correlation between nitrogen content of the leaf and cane yields per acre are obtained at this age. However, in commercial foliar-diagnosis practice, it has been found that leaf samples cannot always be taken at a cane age of 3 months. Then what influence does a delay of 1 or 2 months in sampling have on the foliar values obtained, as compared with a 3-month sampling? Are corrections necessary, and, if so, what are they?

Work done by Ayres (1) in Hawaii in the early 1930's indicated that there was a general decrease in the nutrient content of the sugarcane leaf with age. Clements in a detailed study in Hawaii followed the distribution of nitrogen in the cane plant with increasing age. He proposed in his croplog procedure a Standard Nitrogen Index (SNI) in which the nitrogen level of the leaf could be standardized by use of a formula which took into consideration the moisture content of the leaf sheath and the age of the sample (2). Humbert and Howe (5), in an examination of 6 years' crop-logging information at Ewa Plantation, also found that nitrogen decreased with age

${ }^{1}$ Agronomist, Agricultural Experiment Station, University of Puerto Rico, Rio Piedras P.R. The author wishes to thank Pablo Landrau, Jr., former Associate Agronomist of the Station, for his fine cooperation in the use of data for this work and Severiano Alers-Alers, Research Assistant in Agronomy, for his help in the collection of field data.

2 Italic numbers in parentheses refer to Literature Cited, pp. 169-70. 
and sheath moisture. They presented at formula by which leaf nitrogen could be approximated at any combination of age and sheath moisture.

\section{OBJECTIVE}

However, aside from limited work by Samuels, Capó, and Bangdiwala (8) on the influence of moisture and age on leaf nitrogen, no information had been obtained in Puerto Rico as to the specific influence of the age of the cane on leaf nutrients (N-P-K) in sugarcane.

It was with the purpose of acquiring this information that the work reported here was carried out. This paper reports the results obtained on the influence of age on the leaf-nutrient values in sugarcane.

\section{PROCEDURE}

Sugarcane production in Puerto Rico, as in most cane-growing areas of the world, can be roughly classified as under or without irrigation. The majority of the unirrigated cane in Puerto Rico is grown in areas of abundant rainfall, so that water is not a main limiting factor in production. This cane receiving abundant rainfall will be called "nonirrigated cane" to distinguish it from "irrigated cane" growing in semiarid areas where rainfall is often a major limiting factor of growth.

Data were selected from sugarcane experiments in the nonirrigated and irrigated cane areas to determine the influence of the age of the cane on leaf-nutrient level. For the nonirrigated cane area, the data were derived mainly from three foliar-diagnosis experiments with sugarcane, plus a time-of-planting and harvesting experiment. The experiments were conducted at the Main Station Farm of the Agricultural Experiment Station at Rio Piedras, P.R., the last under the leadership of P. Landrau, Jr., and covered the period 1954-57. The soil type used was a Vega Baja silty clay. The average yearly rainfall for this area is 73 inches. Sugarcane varieties B. 41227 and M. 336 were used in the foliar-diagnosis experiment; for the time-of-planting experiment P.R. 980 was employed. In the foliar-diagnosis experiment leaf samples were taken from three plant canes and two ratoons. Samplings were made approximately every 15 days from cane ages of 1 to 6 months. Twelve replications were taken each time for leaf samples. For the time-of-planting and harvesting experiment, leaf samples were taken from four replicates once every month beginning at 2 months and ending at 6 months of age.

The data for the irrigated cane were selected from a crop-logging experiment at Colonia Esperanza, Mercedita, and various crop-logs from commercial crop-logged cane at Luce and Co., Aguirre. The variety used for both sites was B. 37161, and the data covered the period from 1954-57. Leaf samples of the sugarcane were taken monthly beginning with a cane 
age of 3 months and ending at 18 months for plant canes, and 12 months for ratoons. Eighteen replications were utilized for the crop-log experiment, while averages were obtained from 29 to 91 individual field crop-logs for the commercial crop-logging procedure.

The sugarcane leaf samples were prepared for anlyses as described in a previous publication (9).

\section{RESULTS}

The age of the sugarcane at the time of leaf sampling definitely had an influence on the nutrient level of nitrogen, phosphorus, and potassium in the leaf. The results of all experiments indicated that there was a general decreasing trend of leaf nutrients with increasing age of the cane. The decrease in leaf nutrients with age was very definite in the early stages of cane growth, say up to 6 months of age. After this the decrease continued for some fertilizer elements, whereas there were tendencies for nutrients to increase at a later cane age for others. However, even after these rises in nutrient levels, the leaf values at later ages never reached those found at the early ages of 2 to 3 months.

The findings of the influence of age of cane on the nutrient level in the leaf will be presented for each individual nutrient in order to give a more detailed picture of the results.

\section{NITROGEN}

The results of all experiments indicated that the nitrogen content of the leaf decreases as the age of the sugarcane increases (fig. 1). This decrease with age is not linear throughout the entire growing period because certain factors appear to have an influence on the nitrogen-age relationship. The use of irrigation, the type of crop-plant cane or ratoon, variety, and season of planting all have been found to modify the rate of decrease of leaf nitrogen with cane age.

\section{Nonirrigated vs. Irrigated Sugarcane}

The influence of the age of the cane on leaf nitrogen was found to be of different intensity for cane in nonirrigated areas as compared with irrigated areas. The rate of decrease was much steeper for nonirrigated than for irrigated cane (fig. 1). That is to say nitrogen values in the leaf dropped more rapidly per month of age for nonirrigated than for irrigated cane. A delay in sampling of 1 month produced an average decrease in the leaf nitrogen of 0.23 percent for humid cane, and of 0.09 percent for irrigated cane. The rate of decrease was about $2 \frac{1}{2}$ times as great for nonirrigated as for irrigated cane during the first 7 months.

Age-leaf nitrogen curves from Hawaiian data at Kohala $(6)$ showed a 
similar relationship of nonirrigated to irrigated cane. The rates of decrease of leaf nitrogen per month found from the Hawaiian curves were 0.085 percent for nonirrigated and 0.038 percent for irrigated cane. The rate of decrease was about $21 / 4$ times as great for nonirrigated as for irrigated cane.

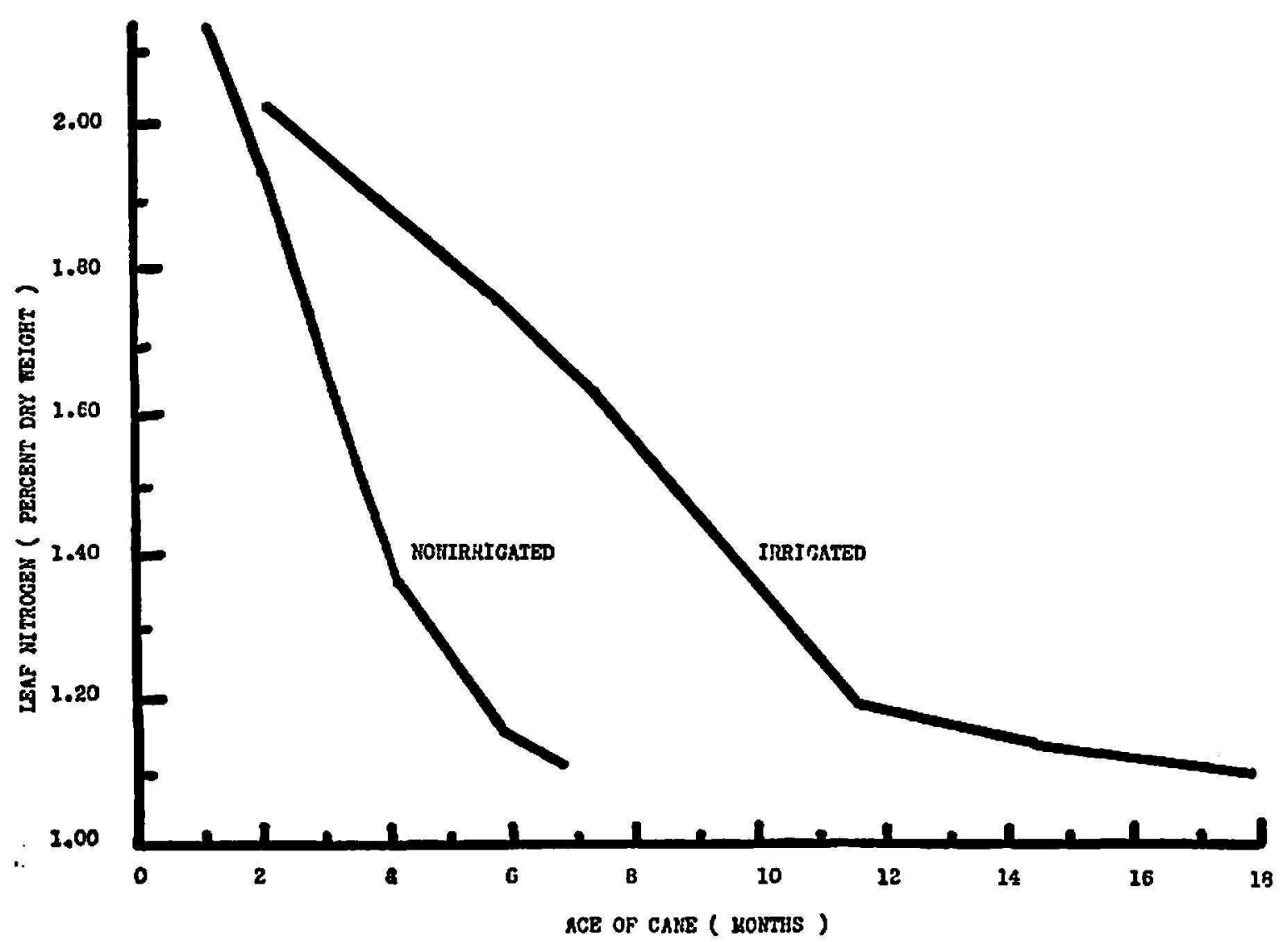

FIG. 1.-The influence of the age of irrigated and nonirrigated cane at sampling on its leaf-nitrogen content.

\section{Type of Crop}

The plant canes did not show the same rate of decrease for leaf nitrogen with age as did the ratoons. The leaf nitrogen declined much more rapidly in ratoons than in plant crops. This was true for both nonirrigated and irrigated sugarcane. For the first 6 months of growth the relation between leaf nitrogen and cane age showed a significant linear correlation which could be expressed in the following equations:

$\begin{array}{lll}\text { Nonirrigated cane: } & \text { Plant cane } & Y n=2.31-0.152 X \\ & \text { Ratoon } & Y n=2.64-0.284 X \\ \text { Irrigated cane: } & \text { Plant cane } & Y n=1.94-0.076 X \\ & \text { Ratoon } & Y n=1.85-0.112 X\end{array}$

where $Y n=$ percentage leaf-nitrogen content on a dry-weight basis and $X=$ age of the sugarcane in months.

The loss of leaf nitrogen in nonirrigated ratoons was 0.28 percent as 
compared with 0.15 percent for plant canes for each 1-month increase in age of the cane. With irrigated cane the loss per month was 0.11 percent of leaf nitrogen for ratoons as compared with 0.08 for plant cane. In both areas ratoons declined at an average rate $13 / 4$ times faster than plant canes.

\section{Varieties}

Data for the varietal influence on the leaf-nitrogen-age relationship were available only for nonirrigated cane. There was no significant difference in the rate of decrease in leaf nitrogen for the three varieties tested: B. 41227, M. 336, and P.R. 980.

Although no varietal age-nitrogen data were available for irrigated canes

TABLE 1.-The decrease in leaf-nitrogen per month for sugarcane-leaf samples taken at various dates throughout the year

\begin{tabular}{l|l|c|c}
\hline Planting date & Period covered by leaf sampling & $\begin{array}{c}\text { Times leaf samples } \\
\text { were taken }\end{array}$ & $\begin{array}{c}\text { Decrease in } \\
\text { leaf-nitrogen values } \\
\text { per month on a } \\
\text { dry-weight basis }\end{array}$ \\
\hline dry & Aug. 18 to Dec. 8 & Number & Percent \\
May 28 & Aug. 31 to Dec. 27 & 5 & 0.19 \\
June 27 & Oct. 1 to Jan. 23 & 5 & .17 \\
July 26 & Oct. 24 to Feb. 20 & 5 & .20 \\
Aug. 23 & Nov. 26 to Mar. 28 & 5 & .20 \\
Sept. 20 & Jan. 23 to Apr. 23 & 4 & .23 \\
Oct. 18 & Feb. 20 to May 21 & 4 & .23 \\
Nov. 15 & Feb. 28 to June 8 & 4 & .22 \\
Dec. 13 & May 21 to July 13 & 3 & .22 \\
Feb. 7 &
\end{tabular}

in Puerto Rico, an examination of the crop-log data in a study at the Hawaiian Commercial and Sugar Co., Ltd., Hawaii (7), showed that there were no significant differences in the slopes of nitrogen-age linear equations for Hawaiian varieties 328560,371933 , and 382915 for the first 12 months of age.

\section{Time of Year}

It did not seem that the time of the year when the leaf samples were taken had any appreciable influence on the nitrogen-age relationship for nonirrigated sugarcane in Puerto Rico. Utilizing a time-of-planting and harvesting sugarcane experiment, leaf samples taken at various grouped intervals throughout the year revealed no significant difference in the slopes of their linear regressions. The changes in leaf nitrogen per month found for these various sampling intervals are given in table 1. Although the slopes of the linear regression were not significantly different when all 
sampling periods were compared, there was a tendency for the lower rates of decrease of nitrogen per month to be associated with samples taken during the period June to December.

The time of the year sugarcane leaf samples are taken was found to influence leaf-nitrogen values, lower values being associated with higher temperatures. Credit for such influence has previously been given to temperature (4). In the spring and summer leaf-nitrogen values are generally lower and the rate of drop is not so great as in the winter when leaf-nitrogen

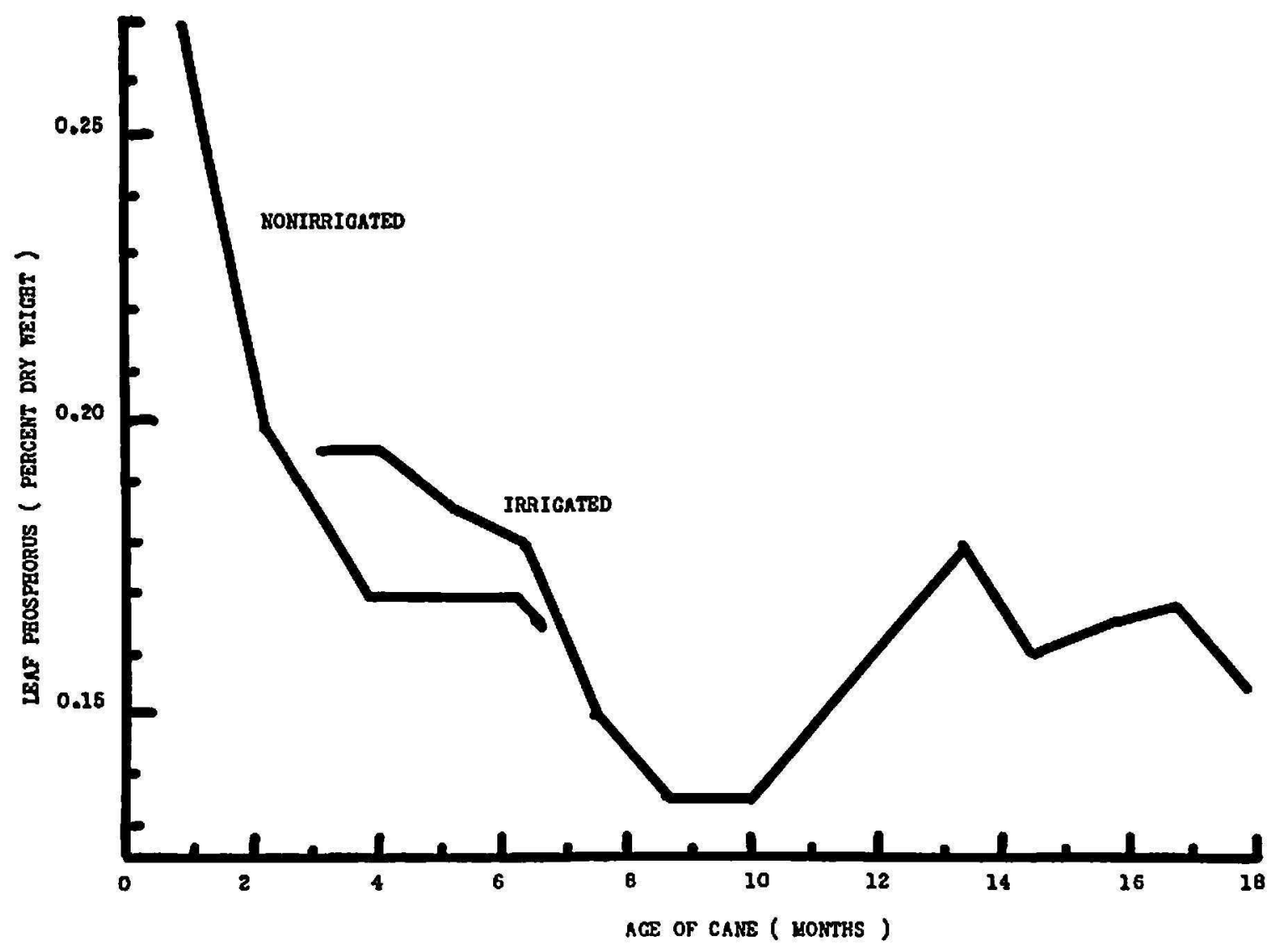

Fro. 2.-The influence of the nge of irrigated and nonirrignted enne at sampling on its lenf-phosphorus content.

values are higher. It appears, however, that these influences were not of sufficient magnitude in Pucrto Rico significantly to influence the leaf-nitrogen-age relationship.

\section{PHOSPHORUS}

The general relationship between leaf phosphorus and age of the sugarcane is shown in figure 2.

Nonirrigated sugarcane showed a sharp decrease in leaf phosphorus from the ages of 1 to 3 months. The drop in leaf phosphorus from 1 to 2 months was about 0.07 percent. At first inspection this does not seem too high a value; but, considering that normal leaf-phosphorus values are about 0.18 
percent at 3 months, it represents a large decrease. The rate of decline was less steep from the ages of about 2 to 6 months, and had decreased to about 0.015-percent leaf phosphorus per month. There was no apparent decrease in leaf phosphorus from the ages of 4 to 6 months. Another decrease in leaf phosphorus occurred between 6 to 7 months, when the study was concluded; it amounted to $\mathbf{0 . 0 1}$ percent for that month.

The rate of decrease for leaf phosphorus was not so rapid in the early months for irrigated as for nonirrigated cane. From 3 to 4 months of age there was no change, and from 4 to 6 months the decrease amounted to about 0.008 percent of leaf phosphorus per month. A more rapid decline was encountered in the 6- to 9-month period, amounting to a decrease of about 0.02 -percent leaf phosphorus per month. There was an increase in leaf phosphorus from 10 to 13 months, so that levels in the leaf equalled those found at 6 months. The leaf phosphorus dropped irregularly after 13 months. Data from Hawaii on irrigated cane also indicated that sheathphosphorus values decreased until a cane age of about 10 months, then increased to about 13 months.

No differences in rate of change of leaf-phosphorus values per month for type of crop were apparent as for leaf nitrogen. The data for plant canes tended to be highly variable, and none of the linear regressions obtained was significant. The relationship between leaf phosphorus and age for the first 6 months was more marked in ratoons and the linear regressions obtained generally proved significant.

Variety differences were not evident in the rate of decrease of leaf phosphorus with age for the nonirrigated canes studied, i.e. B. 41227, M. 336, and P.R. 980.

\section{POTASSIUM}

Leaf potassium did not decrease with age throughout the whole growing period of the sugarcane whether irrigated or not. At first there was a decrease in leaf potassium with increasing age, as was found for leaf nitrogen and phosphorus. However, there was a definite increase in leaf potassium as the cane neared maturity. The variations of leaf potassium with age is shown in figure 3.

There was a sharp decrease in leaf potassium in nonirrigated cane up to an age of 4 months which amounted to about 0.24 percent per month. Between ages of 4 to 5 months the decrease was very much less, being only 0.02 percent of leaf potassium. After 5 months of age the leaf potassium increased; it rose at a rate of around 0.08 percent per month, until about 8 months, at which time the study was concluded.

The pattern of the age-leuf potassium curve for irrigated cane was very similar to that for the nomirigated eane for the first 0 months. The rate of 
decline of leaf potassium was not as sharp for the irrigated as for the nonirrigated cane. It was about 0.18 percent of leaf potassium per month for a cane age of 3 to 5 months. Aside from brief rises at 6 and again at 10 months, the leaf potassium declined rapidly until a cane age of $141 / 2$ months was attained. Then the leaf potassium rose until a cane age of 18 months. In the period from 3 to 14 months the leaf potassium dropped a

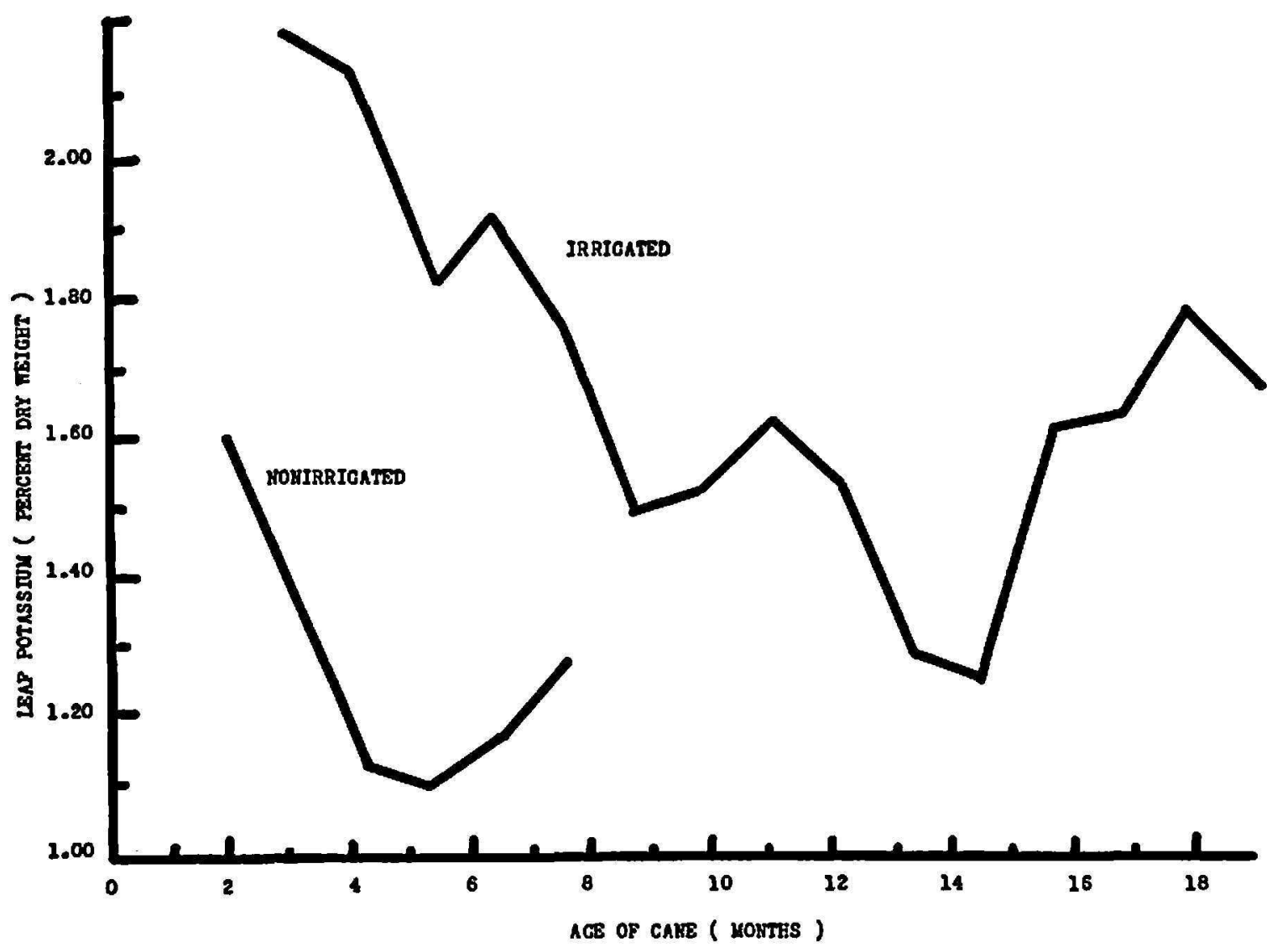

Fra. 3.-The influence of the age of irrigated and nonirrigated cane at sampling on its leaf-potassium content.

total of 0.93 percent in about 11 months. Similar curves were obtained for sheath potassium and age in Hawaii.

\section{DISCUSSION}

The data presented show that the age of the cane does influence the leafnutrient content in Puerto Rico. Leaf-nitrogen levels drop as the age of the cane increases. This relationship is significant, its rate appearing to be modified by type of crop, plant cane or ratoon, and water availability, i.e. nonirrigated or irrigated cane. Phosphorus values do not continue to decrease regularly in the leaf throughout the growth of sugarcane. However, decreases in leaf phosphorus are of sufficient importance in the early months to merit attention. The behavior of leaf potassium with age appears to be somewhat similar to that of leaf phosphorus. 
Sufficient evidence has been collected to be used in making corrections for the influence of age on the leaf-nutrient content. In Puerto Rico, where foliar-diagnosis leaf samples are standardized at a cane age of 3 months, samples taken later than this should be corrected. Inasmuch as most sampling here is limited to a period of about 6 months because of the

TABLE 2.-Correction factors (percent) for the influence of age of the leaf sample on nutrient content ${ }^{1}$

\begin{tabular}{|c|c|c|c|c|c|c|c|}
\hline \multirow{3}{*}{ Nutrient } & \multirow{3}{*}{ Type of crop } & \multicolumn{6}{|c|}{ Correction factor for age of leaf sample 2} \\
\hline & & \multicolumn{3}{|c|}{ Nonirrigated cane } & \multicolumn{3}{|c|}{ Irrigated cane } \\
\hline & & 4 months & 5 months & 6 months & 4 months & 5 months & 6 months \\
\hline Nitrogen & $\begin{array}{l}\text { Plant cane } \\
\text { Ratoon }\end{array}$ & $\begin{array}{r}0.15 \\
.28\end{array}$ & $\begin{array}{r}0.30 \\
.56\end{array}$ & $\begin{array}{r}0.45 \\
.74\end{array}$ & $\begin{array}{r}0.08 \\
.11\end{array}$ & $\begin{array}{r}0.15 \\
.22\end{array}$ & $\begin{array}{r}0.23 \\
.33\end{array}$ \\
\hline $\begin{array}{l}\text { Phosphorus } \\
\text { Potassium }\end{array}$ & $\begin{array}{c}\text { Plant cane or ratoon } \\
\text { do. }\end{array}$ & $\begin{array}{l}.015 \\
.24\end{array}$ & $\begin{array}{l}.015 \\
.24\end{array}$ & $\begin{array}{l}.015 \\
.24\end{array}$ & $\begin{array}{l}0 \\
.12\end{array}$ & $\begin{array}{l}.008 \\
.24\end{array}$ & $\begin{array}{l}.016 \\
.36\end{array}$ \\
\hline
\end{tabular}

1 These values are based on the variation of leaf nutrient for cane up to a cane age of 6 months.

${ }^{2}$ As the standard age of the cane for leaf sampling is 3 months of age, the correction factors are to be added to the leaf-nutrient value obtained when sampled beyond 3 months and up to 6 months of age.

TABLE 3.-Average standard leaf-nutrient values (percent) for sugarcane in Puerto Rico in general on a fertility-status basis

\begin{tabular}{l|c|c|c}
\hline \multirow{2}{*}{ Fertility status } & \multicolumn{3}{|c}{ Leaf-nutrient content, dry-wreight basis, of } \\
\cline { 2 - 4 } & $\mathrm{N}$ & $\mathrm{P}$ & $\mathrm{K}$ \\
\hline Very low & $<1.00$ & $<0.10$ & $<1.00$ \\
Low & $1.00-1.40$ & $0.10-.15$ & $1.00-1.40$ \\
Slightly low & $1.40-1.55$ & $.15-.18$ & $1.40-1.55$ \\
Normal & $1.55-2.00$ & $.18-.24$ & $1.55-2.00$ \\
High & $2.00-2.50$ & $.24-3.0$ & $2.00-3.00$ \\
Very high & $>2.50$ & $>0.30$ & $>3.00$ \\
\hline
\end{tabular}

closing-in of the cane and its shorter growing period-average 12 monthsthese correction factors can best be applied for samples taken up to 6 months. As the leaf-nutrient values decrease with age the correction factors should be added to the leaf values obtained. To assist workers engaged in foliar diagnosis of sugarcane, the suggested correction factors for age of sampling are presented in table 2 and the standard values for 3 months are given in table 3 . For ages beyond 6 months approximate rates of nutrient loss per month can be calculated from the curves presented in figures 1,2 , and 3 . 
It is not to be assumed that the suggested values presented are final. Further work is still needed, especially on phosphorus and potassium.

It would be misleading to give the impression that the age of the sugarcane exerts the greatest influence on nutrient changes in the leaf, aside from the supply of nutrient itself. Moisture cannot be omitted from the picture as to either its direct or indirect effects. In an excellent study of factors affecting the growth of sugarcane Clements $(3)$ showed that leaf nitrogen had a highly significant correlation with sheath moisture and age of cane, the nitrogen correlation with moisture being +0.797 and with age -0.684 , and the sheath-moisture correlation with age being +0.646 . As the cane plant grows older its sheath-moisture and leaf-nutrient (especially nitrogen) values drop. Clements found that the two dominant factors affecting the level of sheath phosphorus were sheath moisture and total sugars. It appears that age was not of significant importance in its effects on sheath-phosphorus levels in irrigated cane in Hawaii.

\section{SUMMARY}

The age of sugarcane exerts a definite influence on the nutrient content of the sugarcane leaf. The effects of age on the leaf-nutrient (N-P-K) content were as follows:

1. There was a decrease in the nitrogen content of the leaf as the cane age increased.

2. The rate of decrease of nitrogen with age was greater for nonirrigated than for irrigated cane, being about $2 \frac{1}{2}$ times as large for the former as for the latter during the first 7 months.

3. Leaf nitrogen declined more rapidly in ratoons than in plant crops.

4. There was no significant difference in rate of nitrogen decline for the varieties tested: B. 41227 , M. 336, and P. R. 980.

5. The time of year the leaf samples were taken had no significant effect on the rate of leaf-nitrogen decline with the age of cane.

6. There was a marked decrease in leaf phosphorus with age of cane in nonirrigated cane up to 4 months, and no change from 4 to 6 months.

7. Irrigated cane decreased in leaf phosphorus, but not quite so rapidly as nonirrigated cane, a decrease apparent until about 9 months. After this the leaf phosphorus began to increase until a cane age of about 14 months, where it once again began decreasing.

8. Leaf potassium did not decrease with age throughout the whole growing period of the sugarcane. At first there was a decrease in leaf potassium with increasing age; however, there was a definite increase as the cane neared maturity. This increase began at about $5 \frac{1}{2} 2$ months for nonirrigated and 15 months for irrigated cane. 
9. A table of suggested correction factors for age of sampling is presented to assist workers engaged in foliar diagnosis of sugarcane.

\section{RESUMEN}

La edad de la planta de caña de azúcar ejerce una influencia definitiva sobre el contenido de nutrientes en sus hojas. Los efectos de la edad sobre el contenido de los nutrientes (N-P-K) se explican a continuación:

1. Hubo una merma del contenido de nitrógeno en la hoja, a medida que aumentaba la edad de la caña.

2. La proporción en que mermó el contenido de nitrógeno según la edad de la planta fué mayor en la caña sin riego que en la que se regó. Durante los primeros siete meses, la proporción de esta merma fué $2 \frac{1}{2}$ veces mayor en la caña sin riego.

3. El nitrógeno en la hoja se redujo más rápidamente en los retoños que en las cañas de plantilla.

4. No hubo una diferencia significativa en cuanto a la proporción de la merma en el contenido de nitrógeno en la hoja para las variedades bajo prueba: B. 41227, M. 336 y P.R. 980.

5. La época del año en que se tomaron las muestras de hoja no demostró ejercer un efecto significativo sobre la proporción de la merma en el contenido de nitrógeno en la hoja con la edad de la caña.

6. Hubo una merma notable en el contenido de fósforo en la hoja relacionada con la edad de la caña sin riego hasta los 4 meses; no se registró cambio alguno de los 4 a los 6 meses.

7. La caña bajo riego sufrió merma en el contenido de fósforo de la hoja, pero no tan rápidamente como lo fué en la caña que no se regó. Esta merma no fué aparente hasta los 9 meses. Después de tener dicha edad, el contenido de fósforo comenzó a aumentar hasta que la caña llegó a los 14 meses, luego de lo cual empezó de nuevo a reducirse.

8. El contenido total de potasio en la hoja no mermó con la edad de la caña a través de todo el periodo de crecimiento de la planta. Al principio hubo una reducción según avanzaba el tiempo; pero ésta fué compensada definitivamente por un aumento continuado a medida que la planta alcanzaba su madurez. Este aumento comenzó a los 51/2 meses en la caña sin riego y a los 15 meses en la caña bajo riego.

9. Se presenta un cuadro con factores de corrección para edad que pueden aplicarse cuando se tomen las muestras y que servirá de ayuda a quienes se dediquen a hacer el diagnóstico foliar de la caña de azúcar.

\section{LITERATURE CITED}

1. Ayres, A., Variation of mineral content of sugarcane with age and season, Haw. Plant Rec. 37 197-206, 1933.

2. Clements, H. F., Crop-logging of Sugarcane: The Standard Nitrogen Index and 
the Normal Nitrogen Index, Univ. Hawaii Agr. Exp. Sta. Tech. Bul. 35, Oct. 1057.

3. Clements, H. F., Sigaura, G., and Akamine, E. K., Factors Affecting the Growth of Sugarcane, Univ. Hawaii Agr. Exp. Sta. Tech. Bul. 18, Sept. 1952.

4. Gómez, Alvarez, F., Influence of Age, Moisture, and Temperature on Leaf Nitrogen in Sugarcane, Estación Experimental de Occidente, Varitagua, Venezuela, Bul. 52, March 1954.

5. Humbert, R. P., and Howe, G. L., An Examination of Six Year's Crop-Logging at Ewa, Exp. Sta. Hawaii Plant. Assoc., Special Release 56, Feb. 1952.

6. Humbert, R. P., and Howe, G. L., An Examination of Seven Year's Crop-Logging at Kohola Exp. Sta. Hawaii Plant Assoc., Special Release 65, Nov. 1952.

7. Humbert, R. P., and Silva, J. A., An Examination of Five Years of Crop-Logging at Hawaiian Commercial and Sugar Co., Ltd., Exp. Sta., Hawaii Plant. Assoc., Special Release 88, Feb. 1954.

8. Samuels, G., Capó, B. G., and Bangdiwala, I., The nitrogen content of sugar-case as influenced by moisture and age, J. Agr. Univ. P.R. 37 1-12, 1953.

9. Samuels, G., Landrau, P., Jr., Alers-Alers, S., and Riera, A., The Method of Foliar Diagnosis, Agr. Exp. Sta. Univ. P.R. Bul. 123, Feb. 1955. 